\title{
Clinical Impact of Association Between Diabets and Lung Cancer
}

\author{
LAURA MAZILU1, DANA LUCIA STANCULEANU², ANDREEA DANIEL A GHEORGHE ${ }^{1}$, ADRIAN PAUL SUCEVEANU', \\ IRINEL RALUCA PAREPA ${ }^{1}$, ANCA PANTEA STOIAN ${ }^{2 *}$, ANDRA-IULIA SUCEVEANU ${ }^{1}$ \\ ${ }^{1}$ Ovidius University, Faculty of Medicine, Universitatii Str., 900470, Constanta, Romania \\ ${ }^{2}$ Carol Davila University of Medicine and Pharmacy, 8 Eroii Sanitari Str., 050474, Bucharest, Romania
}

\begin{abstract}
The main objective of this analysis is to evaluate the impact of lung cancer and diabetes association on cancer treatment and outcome of lung cancer patients. Lung cancer, as well as diabetes mellitus, are two diseases with very high prevalence. Lung cancer, despite the improvement in diagnosis and therapeutic methods, is still the $1^{\text {st }}$ cause of cancer-related deaths. The influence of diabetes on cancer patients survival is well established among patients with hepatic, pancreatic or breast cancer. Diabetes implication on lung cancer outcome is not well known. Several studies reported a negative impact, whereas other studies reported a better prognosis for these patients. Our study took place in the Oncology Department of the Clinical Emergency Hospital of Constanta, Romania. 80 patients with diagnosis of non-small cell lung cancer were elected to participate in this study; 29 patients had also diabetes. Selected patients were divided in 2 groups, one group of lung cancer and diabetes, and one group without diabetes. Features of the patients among both groups were analyzed. Ou study showed that preexisting diabetes is an unfavorable factor, and has influence on lung cancer prognosis, treatment adhesion and quality of life. To amend the outcome of patients with lung cancer, a better evaluation of patients' co-morbidities, including diabetes mellitus, is required.
\end{abstract}

Keywords: lung cancer, diabetes mellitus, prognosis.

Lung cancer and diabetes mellitus are two diseases with very high prevalence worldwide [1,2]. Lung cancer, as primary tumor or metastatic [3-6], despite the improvement in diagnosis and therapeutic methods, remains the $1^{\text {st }}$ cause of cancer-related deaths [7]. Diabetes mellitus also has a high prevalence, and its prevalence is increasing every year [8]. In order to improve the outcome of these patients, a better understanding of factors influencing lung cancer' outcome is required. Besides the well-known risk factors (smoking, age), diabetes may be an important prognostic factor in lung cancer population [9]. The negative influence of diabetes on survival of cancer patients is well established among patients with hepatic, pancreatic or breast cancer [10-12]. Diabetes impact on lung cancer prognosis is not well known, several studies reported a negative impact, whereas other studies reported a better prognosis for these patients $[13,14]$.

It is important to know and understand more about lung cancer and diabetes association, in order to offer better care for these patients.

\section{Experimental part \\ Methods}

This observational descriptive study took place in the Oncology Department of the Clinical Emergency Hospital of Constanta, Romania, on a group of 80 patients with lung cancer, during a period of time of two years. Patients were informed about the objectives of this analysis and about privacy and confidentiality rights. A signed informed consent form was obtained from all the patients before entering the study. All informations about the patients were obtained using medical records of the Department. To assess the quality of life, FACT-G and NTX questionnaire were used. The questionnaires were completed by the medical staff during interview and medical history of the patients. Written permission was obtained to use the FACT-G scale. Statistical analyses were performed using the Statistical
Package for the Social Sciences version 10.0 software (SPSS).

\section{Results and discussions}

The study included 80 patients with a diagnosis of lung cancer. 29 of these patients had associated diabetes (35.25\%). Selected patients were divided into 2 groups, according to the presence or absence of diabetes. Characteristics and comparisons of the 2 groups are described in Table 1. Men were the majority in both groups. Median age was $63.76 \pm 7.6$ years for lung cancer patients with diabetes, and $62.06 \pm 7.3$ years for non-diabetic patients with lung cancer. Smoker population was prevalent in both groups. Regarding alcohol consumption, the percentage of patients using alcohol was higher in nondiabetic subgroup. In both subgroups we found patients with co-morbitidies, but in the diabetic subgroup the incidence of arterial hypertension, cardiac disease and stroke was higher. With respect to histology in both groups, the squamous-cell carcinoma and adenocarcinoma had higher frequency. The stage of the lung cancer at diagnosis was advanced or metastatic in both groups, only few percentages had early stages.

Regarding treatmentmodalities, we found no significant differences between groups, but we found a significant difference between the number of chemotherapy cycles. In our study, diabetic patients with lung cancer had a lower number of chemotherapy cycles, and more frequent treatment interruptions. Performance status was assessed with ECOG scale, and no significant difference was found between groups, except for patients with low performance status ( $E C O G=3$ ), who were found with higher frequency in diabetes group. Neuropathy was more frequent in the diabetes group, and also the grade of neuropathy was higher.

Quality of life (QoL) was evaluated using FACT-G scale, and neuropathy was evaluated using NTX scale. Permission to use these scales was obtained. No differences were 
found in QoL of the patients with diabetes, except for the presence of neuropathy.

Regarding survival of patients, comparison between groups showed that diabetes directly influences the survival of patients with lung cancer.

The mechanism by which diabetes impacts the survival of patients with lung cancer is not yet fully known. Some literature data shows that the presence of diabetes does not influence survival [15], while other data shows that the presence of diabetes could even improve survival of patients with lung cancer, and that chronic vascular changes found in diabetes restrict metastasis [16-18].

It is known, however, that the presence of diabetes influences the progression of cancer through different mechanisms, such as hyperglycemia, hyperinsulinemia and chronic inflammation associated with cellular proliferation [19-24].
In our study, data shows that the presence of diabetes influences the survival and outcome of patients with lung cancer in an adverse manner [25]. The data obtained in this analysis showed a 13.62 months survival for patients without diabetes, and 10.31 months for patients with diabetes.

Diabetes also negatively influences treatment tolerance, and may influence the clinicians' decision regarding the treatment options in patients with both diabetes and lung cancer.

Quality of life of patients from our study, with diabetes and lung cancer, was also negatively influenced, especially by the presence of neuropathy, that can be determined by both diabetes and chemotherapy [26-31].

This study has some limitations, related to the small number of patients included and the short period of the study.

Table 1

CHARACTERISTICS OF PATIENTS INCLUDED IN THE STUDY

\begin{tabular}{|c|c|c|c|c|}
\hline Characteristic & $\begin{array}{l}\text { Diabetes }+ \\
(n=29)\end{array}$ & $\begin{array}{l}\text { Diabetes - } \\
(\mathrm{n}=51)\end{array}$ & $\begin{array}{l}\text { P value } \\
\text { Analysis } \\
\text { groups }\end{array}$ & between \\
\hline Age & $63.76 \pm 7.6$ & $62.06 \pm 7.3$ & $\mathrm{P}>0.05$ & \\
\hline $\begin{array}{l}\text { Sex } \\
\text { Male } \\
\text { Female }\end{array}$ & $\begin{array}{l}25(86.2 \%) \\
4(13.8 \%)\end{array}$ & $\begin{array}{l}38(74.5 \%) \\
13(25.5 \%)\end{array}$ & $P=0.224$ & \\
\hline $\begin{array}{l}\text { Area } \\
\text { Rural } \\
\text { Urban }\end{array}$ & $\begin{array}{l}17(58.6 \%) \\
12(41.4 \%)\end{array}$ & $\begin{array}{l}31(60.8 \%) \\
20(39.2 \%)\end{array}$ & $P=0.852$ & \\
\hline $\begin{array}{l}\text { Smoking status } \\
\text { Smokers } \\
\text { Non-smokers }\end{array}$ & $\begin{array}{l}26(89.7 \%) \\
3(10.3)\end{array}$ & $\begin{array}{l}43(84.3 \%) \\
8(15.7 \%)\end{array}$ & $P=0.511$ & \\
\hline $\begin{array}{l}\text { Alcohol } \\
\text { Yes } \\
\text { No }\end{array}$ & $\begin{array}{l}9(31.0 \%) \\
20(69.0)\end{array}$ & $\begin{array}{l}22(43.1 \%) \\
9(56.9 \%)\end{array}$ & $P=0.291$ & \\
\hline $\begin{array}{l}\text { Comorbidities } \\
\text { Arterial Hypertension } \\
\text { Stroke } \\
\text { Ischemic cardiac disease }\end{array}$ & $\begin{array}{l}14(48.27 \%) \\
5(17.24 \%) \\
3(10.34 \%)\end{array}$ & $\begin{array}{l}16(31.37 \%) \\
3(5.88 \%) \\
3(5.88 \%)\end{array}$ & $\begin{array}{l}P<0.05 \\
P<0.05 \\
P<0.05\end{array}$ & \\
\hline $\begin{array}{l}\text { Histology } \\
\text { Adenocarcinoma } \\
\text { Squamous } \\
\text { Other }\end{array}$ & $\begin{array}{l}12(41.4 \%) \\
15(51.7 \%) \\
2(6.9 \%)\end{array}$ & $\begin{array}{l}22(43.1 \%) \\
26(51.0 \%) \\
3(5.9 \%)\end{array}$ & $P=0.978$ & \\
\hline $\begin{array}{l}\text { Lung cancer stage } \\
\text { II } \\
\text { III } \\
\text { IV }\end{array}$ & $\begin{array}{l}2(6.9 \%) \\
8(27.6 \% \\
19(65.5 \%)\end{array}$ & $\begin{array}{l}5(9.8 \%) \\
23(45.1 \%) \\
23(45.1 \%)\end{array}$ & $P=0.217$ & \\
\hline $\begin{array}{l}\text { Treatment } \\
\text { Surgery } \\
\text { Yes } \\
\text { No }\end{array}$ & $\begin{array}{l}4(13.8 \%) \\
24(82.8 \%)\end{array}$ & $\begin{array}{l}8(15.7 \%) \\
42(82.4)\end{array}$ & $P=0.843$ & \\
\hline $\begin{array}{l}\text { Radiotherapy } \\
\text { Yes } \\
\text { No }\end{array}$ & $\begin{array}{l}7(24.1 \%) \\
22(75.9 \%)\end{array}$ & $\begin{array}{l}9(17.6 \%) \\
42(82.4 \%)\end{array}$ & $P=0.492$ & \\
\hline $\begin{array}{l}\text { Chemotherapy no of cycles } \\
\leq 5 \\
\geq 6\end{array}$ & $\begin{array}{l}22(75.86 \%) \\
7(24.13 \%)\end{array}$ & $\begin{array}{l}16(31.37 \%) \\
35(68.27 \%)\end{array}$ & $P<0.05$ & \\
\hline $\begin{array}{l}\text { ECOG status } \\
0 \\
1 \\
2 \\
3\end{array}$ & $\begin{array}{l}11(37.93 \%) \\
8(27.58 \%) \\
6(20.68 \%) \\
4(13.79 \%)\end{array}$ & $\begin{array}{l}20(39.21 \%) \\
16(31.37 \%) \\
10(19.6 \%) \\
5(9.8 \%)\end{array}$ & $\begin{array}{l}P>0.05 \\
P<0.05\end{array}$ & \\
\hline $\begin{array}{l}\text { Neuropathy } \\
\text { Yes } \\
\text { No }\end{array}$ & $\begin{array}{l}24(82.8 \%) \\
5(17.2 \%)\end{array}$ & $\begin{array}{l}21(42.0 \%) \\
28(56.0 \%)\end{array}$ & $P<0.01$ & \\
\hline $\begin{array}{l}\text { Neuropathy Grade } \\
1 \\
2 \\
3\end{array}$ & $\begin{array}{l}11(37.9 \%) \\
13(44.8 \%) \\
1(3.4 \%)\end{array}$ & $\begin{array}{l}12(24.0 \%) \\
8(16.0 \%) \\
1(2.0 \%)\end{array}$ & $P=0.03$ & \\
\hline FACT-G score & 51.76 & 53.07 & $P>0.05$ & \\
\hline NTX score & 4.92 & 6.66 & $\mathrm{P}<0.05$ & \\
\hline
\end{tabular}




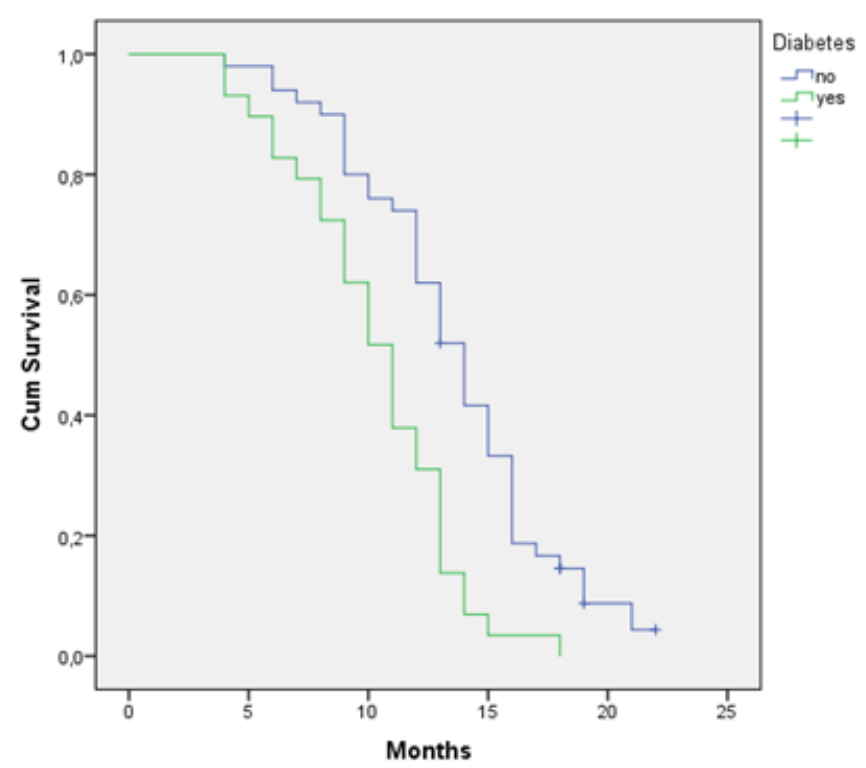

rig. 1. Survival of the lung cancer patients with and without diabetes.

\section{Conclusions}

Findings in this study shows that the presence of diabetes negatively impact the survival of patients with lung cancer, the quality of live and adherence to treatment.

\section{References}

1.SIEGEL, R.L., MILLER, K.D., JEMAL, A., CA Cancer J. Clin., 66, no.1, 2016, p.7.

2.*** CENTER FOR DISEASE CONTROL AND PREVENTION. CENTERS FOR DISEASE CONTROL AND PREVENTION, US DEPT OF HEALTH AND HUMAN SERVICES; ATLANTA, GA: 2015. DIABETESREPORT CARD 2014 www.cdc.gov/diabetes/pdfs/library/diabetesreportcard2014.pdf. 3.MARCU, D., SPINU, D., MISCHIANU, D., SOCEA, B., OPREA, I., BRATU, O. Romanian J ournal of Military Medicine, 120, no. 3, 2017, p. 39-42.

4.POPESCU, R., BRATU, O., SPINU, D., MARCU, D., FARCAS, C., DINU, M., MISCHIANU, D. Romanian J ournal of Military Medicine, 118, no. 3, 2015, p. 16-19.

5.BRATU, O.G., MARCU, R.D., SOCEA, B., NEAGU, T.P., DIACONU, C.C., SCARNECIU, I., TURCU, F.L., RADAVOI, G.D., BRATILA, E., BERCEANU, C., SPINU, A.D. Rev Chim (Bucharest), 69, no. 7, 2018, p. 1813-1816.

6.NITIPIR, C., GINGHINA, O., POPA, L.,et al.,Molecular and Clinical Oncology, 8, no.4,2018,p. 595-599

7.PARASCHIV, B., TOMA, C.L., DIACONU, C.C. Archivos de Bronconeumología, 49, no. 7, 2013, pp. 315-316.
8.DIACONU, C., NASTASA, A., ZAKI, A.R., ARSALAN, M. The 2nd International Conference on Interdisciplinary Management of Diabetes Mellitus and its Complications - Diabetes mellitus as cardiovascular disease, INTERDIAB 2016 Proceedings, 2016, pp 201-210. Ed. Niculescu. Editors Cristian Serafinceanu, Octavian Negoita, Viviana Elian.

9.DIACONU, C.C., ARSENE, D., PARASCHIV, B., BALACEANU, A., BARTOS, D. Acta Endocrinologica, IX, no. 4, 2013, pp.637-642. 10.TOYODA, H., KUMADA, T., NAKANO, S., TAKEDA, I., SUGIYAMA, K., KIRIYAMA, S., TANIKAWA, M., SONE, Y., HISANAGA, Y., Cancer, 91, 2001, p. 957.

11.YANCIK, R., WESLEY, M.N., RIES, L.A., HAVLIK, R.J., EDWARDS, B.K., YATES, J.W., JAMA, 285, 2001, p.885-892.

12.DE GIORGIO, R., BARBARA, G., CECCONI, A., CORINALDESI, R., MANCINI, A.M., Arch Intern Med.,160, 2000, p.2217.

13.HATLEN, P., GRØNBERG, B.H., LANGHAMMER, A., CARLSEN, S.M., AMUNDSEN, T., J Thorac Oncol.,6, 2011, p.1810-1817.

14.ZHU, L., CAO, H., ZHANG, T., ET AL., Medicine (Baltimore), 95, no. 17, 2016, p.e3528.

15.BALACEANU, A., DIACONU, C., MATEESCU, D., STANICA, A. Medical Ultrasonography, 12, no. 4, 2010, pp. 345-348.

16.HANBALI, A., AL-KHASAWNEH, K., COLE-J OHNSON, C., DIVINE, G., ALI, H., Arch Intern Med., 167, 2007, p.513.

17.SATOH, H., ISHIKAWA, H., KURISHIMA, K., OHTSUKA, M., SEKIZAWA, K., Arch Intern Med.,161, 2001, p.485.

18.TAMMEMAGI, C.M., NESLUND-DUDAS, C., SIMOFF, M., KVALE, P., Int J Cancer, 103, 2003, p.792-802.

19.GARCIA-JIMENEZ, C., GARCIA-MARTINEZ, J.M., CHOCARRO-CALVO, A., DE LA VIEJA, A., J Mol Endocrinol., 52, no.1, 2014, p.R51-R66. 20.MORSS, A.S., EDELMAN, E.R.,J Biol Chem., 282, no.19, 2007, p.1463514644.

21.DIACONU, C.C., ARSENE, D., BALACEANU, A., BARTOS, D. Romanian J ournal of Morphology and Embryology, 55, no. 3, 2014, pp. 973-976. 22.NISIPEANU, S.E., PECE, S., IVAN, I.M., et al.,Environmental Engineering And Management J ournal,13, no.6,2014,p. 1537-1541 23.CULMAN, M., GUJ A, C., MIHAl, A.,et al.,Romanian J ournal Of Legal Medicine,21,no.3,2013,p.197-200

24. STROESCU BALCANGIU, A.E., TANASESCU, M.D., DIACONESCU, A., et al., Rev. Chim. (Bucharest), 69, no.11, 2018, p.4018-4021 25.IOAN, B. Revista Romana de Bioetica, 9, no. 4, 2011, p. 3-4.

26.MARCU, D., SPINU, D.,MISCHIANU, D.,et al.,Romanian J ournal of Military Medicine,120,2017, no. 3,p. 39-42.

27. LOSTUN, A.,LOSTUN, G., HAINAROSIE, R., Rev. Chim. (Bucharest), 67, 2016, no.8, p.1587.

28.TOTU, E.E., MANUC, D., Rev. Chim. (Bucharest), 59, no.9, 2008, p. $947-951$

29.GAVRILA, R., ISAILA, M., MIRCIOIU, C., et al., Farmacia, 66, no.6, 2018, p.930-937

30.GHERGHICEANU, F., SANDULOVICI, R., PRASACU, I., et al., Farmacia, 64, no.6, 2016,p. 823-827

31.NITIPIR, C., BAETU, A., VOINEA, A., et al.,Rev. Chim. (Bucharest), 69, no.12, 2018, p. 3427-3432

Manuscript received: 7.12 .2018 